\title{
Anatomical and Clinical Considerations of the Pectoralis Tertius Muscle in Man
}

\author{
Consideraciones Anatómicas y Clínicas del Músculo Pectoral Tercero en el Hombre
}

"Mariano del Sol; \& ** Bélgica Vásquez

DEL SOL M. \& VÁSQUEZ, B. Anatomical and clinical considerations of the pectoralis tertius muscle in man. Int. J. Morphol., 27(3):715-718, 2009.

SUMMARY: The anatomical variation of the major pectoral muscles is infrequent, namely the agenesis of the pectoralis major muscle due to the morpho-functional alterations it causes. On the other hand, he presence of -supernumerary - pectoral muscles is not common and its physiological, clinical or surgical importance will depend on the stage of its development. The important aspect is that these muscles, while crossing the anterior wall of the axila and inserting in the humerus, may confuse or difficult surgical access to the content of the axillary fossa. Pectoralis tertius muscles were found in two dissected cadavers at the Topographic Anatomy of the Faculty of Medicine of the Universidad de La Frontera, Chile. These muscles were bilateral and independent of the pectoralis major muscle. They originated in the external face of the sixth rib and adjacent regions, and inserted in the coracoid process, the crest of the greater tubercle of the humerus, or next to the insertion of the pectoralis major muscle, contributing to the formation of the anterior wall of the axila. The supernumerary muscles crossing the axillary region, whether in an arched form or elongated as the pectoralis tertius muscles, may confuse the surgeon at the entrance of the axila. In view of the above, it is always necessary to consider the possible existence of this type of anatomical variation.

KEY WORDS: Pectoral tertius muscle; human anatomy; muscular variation.

\section{INTRODUCTION}

The pectoralis major muscle normally originated in the sternum middle of the clavicle, the sternum, the rib cartilage $2^{\text {nd }}$ to $6^{\text {th }}$ of the sixth rib and the aponeurosis of the external oblique muscle of the abdomen. The muscle is inserted in the lateral lip of the intertubercular sulcus of the humerus through the two lamina: anterior and posterior (Williams et al., 1995). However, the insertion of the pectoralis major muscle can be made through the supernumerary muscular fascicles at other points such as: coracoid process or over the tendon of the coracobrachialis muscle (Bertelli in Balli et al., 1932) ); over the fascia of the arm (Debiére,1890); in the greater tubercle of the humerus (Bertelli in Balli et al.; Testut, 1887), in the lesser tubercle of the humerus (Testut); over the capsule of the shoulder joint (Debiére; Bertelli in Balli et al.), over the short head tendon of the biceps brachii muscle (Debiére; Bertelli in Balli et al.); in the medial epicondyle of the humerus (Bacelar, 1965; Da Costa, 1961; del Sol \& Vieira,
1989; Dharap, 1994; Lambertini, 1972; Le Double, 1987; Tavares).

Supernumerary fascicles of the pectoralis major muscle, with an independent origin and insertion can be considered as a pectoralis tertius muscle, which, according to its relation to the axillary walls and contents, may constitute difficulty in the access of the area.

\section{MATERIAL AND METHOD}

This work has been carried out on the usual specimens, which belong to the Topographical Anatomy courses from the Faculty of Medicine, Universidad de La Frontera, Chile. Observations were performed in 108 formalinized corpses from adult male individuals. Pectoral

\footnotetext{
" Faculty of Medicine, Universidad de La Frontera, Temuco, Chile.

**Universidad Autónoma de Chile, Sede Temuco, Chile.
} 
dissection was performed at the infraclavicular fossa, clavipectoral triangle, pectoral region, mammary and inframammary regions, axillary region and axillary fossa beside deltoid and brachial regions.

\section{RESULTS}

Two muscular variations of the supernumerary fascicles of the anterior face of the thorax are described, considered as pectoralis tertius muscles. These bilateral muscles were found during routine dissections in two adult male cadavers.

In the first case both pectoral tertius muscles originated through interposed muscular fibers along with short tendinous fibers, in the external face of the sixth rib, next to its medial extremity, and the anterior face of the costochondral joint. The insertions were made by three small flat tendons in: a) coracoid process (principal tendon); b) crest of the greater tubercle of the humerus and c) fascia of the pectoralis minor muscle (Figs.1a, 1b and 2).

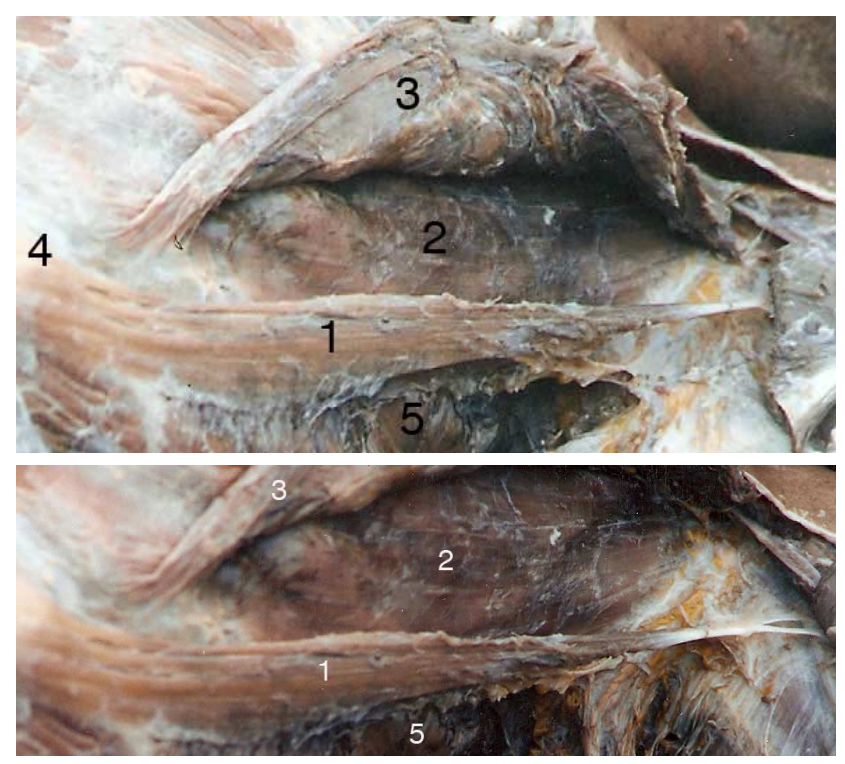

Figs. 1a and 1b. 1. Pectoral tertius muscle; 2. Pectoral minor muscle; 3. Pectoral major muscle; 4. VI Costal cartilage; 5. Serratus anterior muscle.

In the second case, the third pectoral muscles were flat and triangular fascicles at the thoracic base. They originated from the external face of the sixth rib, extending to adjacent areas until the seventh rib and the seventh costal cartilage, at that level intertwining with the fibers of the external oblique muscle of the abdomen. The insertions were made through a flattened tendon plate, at the level of the

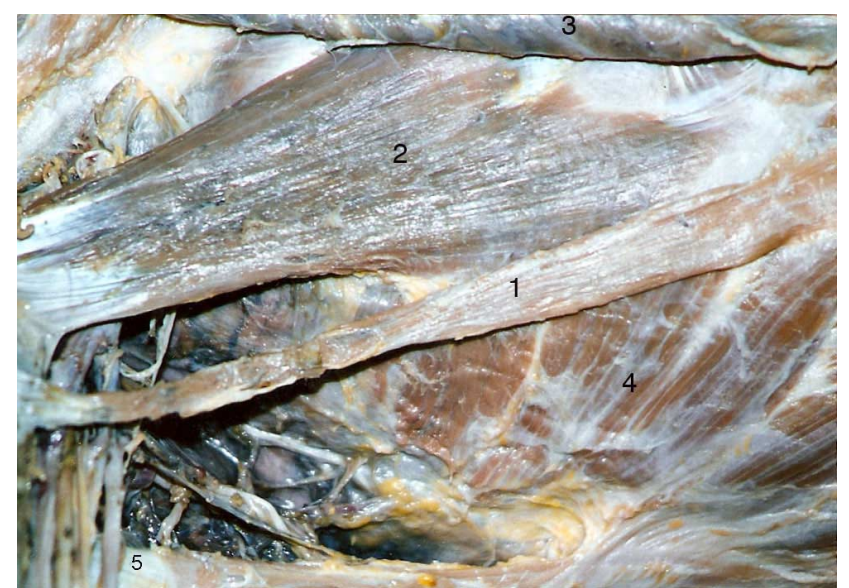

Fig. 2. 1. Pectoral tertius muscle; 2. Pectoral minor muscle; 3. 3. Pectoral major muscle; 4. Serratus anterior muscle; 4. Axillary fossa; 5 . Tendon of the latissimus dorsi muscle.
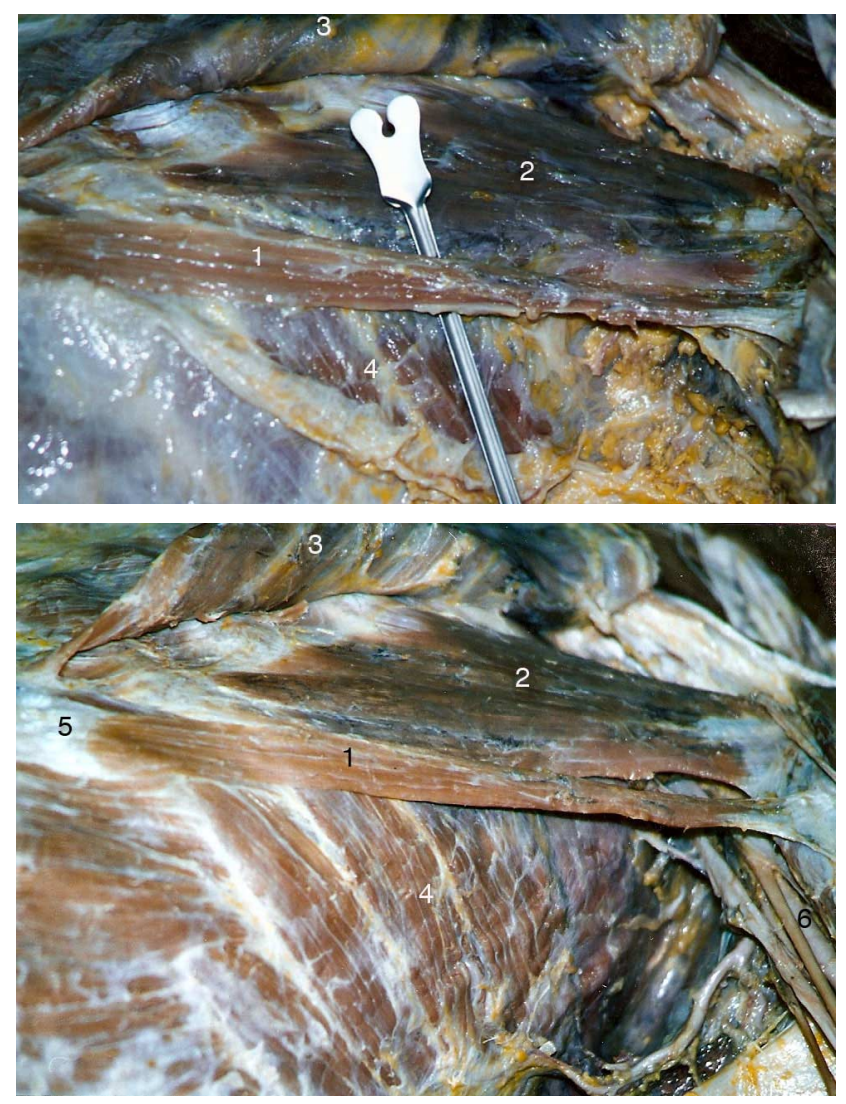

Figs. 3a and 3b. 1. Pectoral tertius muscle; 2. Pectoral minor muscle; 3. Pectoral major muscle; 4. Serratus anterior muscle; 5. VI Costal cartilage; 5. Axilar artery.

fascia of the brachialis and coracobrachialis bicep muscles. However the major part of the tendinous fibers, followed deeply to the deltoid muscle, contouring the greater tubercle of the humerus where they completed their insertion. (Figs. $3 a$ and $3 b)$. 
The relation of the pectoralis tertius muscles, were with the inferolateral margin and the deep lateral face of the pectoralis major muscle, presenting a parallel trajectory at that edge. In addition, due to the depth they related with the ribs and external intercostal muscles. At the level of insertion in the humerus they formed part of the anterior wall of the axila.

Innervation came from the branches of the lateral pectoral nerve, that reached the muscle due to its deep face.

\section{DISCUSSION}

Reports in relation to the existence of muscular variations at the level of the axila, are relatively frequent, especially the muscular arches or axipectoral muscles of Langer (del sol et al., 1983; Dharap, 1994; Kalaycioglu, 1998; Sachatello, 1977; Testut; Willimas et al.). However, few cases can be found in literature regarding pectoralis tertius muscles (del Sol et al., 1994; Le Double; Testut). The presence of this type of variation must be informed, as it is an area where surgical procedures are frequently performed.

The axillary muscular arches generally extend between the tendon of the latissimus dorsi muscle and pectoralis major muscle or the coracoid process, in consequence, are considered as pectorodorsal muscular fascicles; on the other hand, the pectoral tertius muscle is pectoroventral. Thus, considering the pectoralis tertius muscle as a supernumerary fascicle of the pectoralis major muscle, whatever its insertion, it may be separated from the deep face or present simple continuous relation to this muscle (Testut).

The pectoralis tertius muscle, in accordance with our observations must be considered a costobrachialis muscle, absolutely different from the pectoralis major muscle which is located in the anterior area, and also different from the minor pectoralis muscle, which is directed to the coracoide process by a single tendon.

As can be observed in the figures, the pectoralis tertius muscle forms the anterior line of the axial and part of its anterior wall, similar to what occurs with the condroepicondylar muscle (del Sol \& Vieira; Le Double). However, the relation in this latest one are more ample as it must reach the cubital region.

The pectoralis tertius muscle is of an origin similar o the chondroepicondylar muscle (Macalister, 1871). For many authors (Bacelar; Da Costa; del Sol \& Vieira; Fonzone \& Mensorio, 1968, Lambertini; Tavares. ) the chondroepicondylar muscle is a rudimentary fascicle or thoracic origin and insertion in the medial epicondylus of the humerus, which can be compared to the extensor plicae alaris muscle of the birds.

In other investigations (Testut) the presence of a different fascicle stands out, one which originates in the fifth rib, along the inferior margin of the pectoralis major muscle, passing beneath this muscle at the level of the axila and divides, to a $3 \mathrm{~cm}$ medial intertubercular sulcus, in two fascicles: the superior fascicle inserted over the free end of the intertubercular sulcus, posterior to the tendon of the pectoralis major muscle, and the inferior fascicle which spreads over a round tendon that descends to the medial epicondyle of the humerus. In this case, the superior fascicle would represent the third pectoral muscle and the inferior of the chondroepicondylar muscle.

According to the research in literature of the muscular variations a the level of the axial, we can state that the intermediate pectoralis muscle, so denominated, pectoralis quartus muscle by some authors, is normal in Gorillae and in Cynocephale sphinx (mandrill) and would be none other than the pectoralis tertius muscle, which is referred to in this investigation.

DEL SOL M. \& VÁSQUEZ, B. Consideraciones anatómicas y clínicas del músculo pectoral tercero en el hombre. Int. J. Morphol., 27(3):715-718, 2009.

RESUMEN: La variación del músculo pectoral mayor es frecuente, siendo la agenesia de este músculo causante de alteraciones morfofuncionales. Por otro lado, la presencia de un músculo pectoral supernumerario no es común y su importancia fisiológica, clínica o quirúrgica va a depender del estado de su desarrollo. Los importancia de estos músculos radica en que ellos cruzan la pared anterior de la axila y se insertan en el húmero, lo que puede confundir o dificultar el acceso quirúrgico al contenido de la fosa axilar. Músculos pectorales terceros fueron encntrados en dos cadáveres disecados en la Facultad de Medicina de Universidad de La Frontera, Chile. Estos músculos eran bilaterales e independientes del músculo pectoral mayor. Ellos se originaban en la cara externa de la sexta costilla y regiones adyacentes y se insertaban en el proceso coracoides, cresta del tubérculo mayor del húmero o próximo a la inserción del músculo pectoral mayor, contribuyendo a la formación de la pared anterior de la axila. Los músculos supernumerarios que cruzan la región axilar, ya sea en una forma arqueada o alargada como los músculos pectorales terceros, pueden confundir al cirujano en la entrada a la axila. En vista de lo anterior, siempre es necesario considerar la posible existencia de este tipo de variaciones anatómicas.

PALABRAS CLAVE: Músculo pectoral tercero; Anatomía humana; Variación anatómica. 
DEL SOL M. \& VÁSQUEZ, B. Anatomical and clinical considerations of the pectoralis tertius muscle in man. Int. J. Morphol., 27(3):715-718, 2009.

\section{REFERENCES}

Bacelar, A. Nota sobre dois casos de variações musculares. Arq. Anat. Antropol., 33:107-15, 1965.

Bertelli, D. Miologia. In Balli, R. et al. Trattato di anatomia umana. $2^{\text {nd }}$ ed. Francesco Vallardi, Milano, 1932.

Cruveilhier, J. Traité d'anatomie descriptive. $6^{\text {nd }}$ ed. Asselin, Paris, 1877.

Da Costa, V. B. Algumas variações musculares. Arq. Anat. Antropol., 31:353-63, 1961.

Debiere, C. H. Traité élémentaire d'anatomie de l'homme. Félix Ancan, Paris, 1890.

Del Sol, M. \& Vieira, M. C. Anatomia do músculo condroepicondilar. F. méd., 99(1):5-7, 1989.

Del Sol, M.; Olave, E. \& Méndez, A. Variación muscular. Un caso de arco muscular de la axila. Rev. Chil. Cs. Méd. Biol., 3(2):83-85, 1993.

Del Sol, M.; Méndez, A.; Aguilar, M.; Lasalle, M. A.; Jarpa, C. \& López, P. Músculo pectoral tercero. Rev. Chil. Cs. méd. Biol., 4:57-61, 1994.

Dharap, A. An unusually medial axillary arch muscle. $J$. Anat., 184:639-41, 1994

Fonzone, L. \& Mensorio, C. Su di caso di muscolo cóndorepitrocleare di Wood osservato nel vivent. Quad. Anat. Prat., 24:1-4, 1968.

Kalaycioglu, A.; Gümüsalan, Y. \& Ozan, H. Anomalous insertional slip of latissimus dorsi muscle: arcus axillaris. Surg. Radiol. Anat., 20:73-75, 1998.

Lambertini, G. Description de nombreuses variations musculaires controlées sur le vivants au cours de trente années d'observations. Bull. Assoc. Anat., 155:1298-302, 1972.

Le Double, A. F. Traité des variations du système musculaire de l'homme, Schleicher Frères, Parism 1897.

Macalister, A. Muscular anomalies in human anatomy, University of Dublín, Dublín, 1871.

Miguel, M.; Llusá, M.; Ortiz, J. C.; Porta, N.; Lorente, M. \& Götzens, V. The axillopectoral muscle (of Langer): report of three cases. Surg. Radiol. Anat., 23:341-3, 2001.
Sachatello, C. R. The axillopectoral muscle (Langer's axillary arch): A cause of axillary vein obstruction. Surgery 81:610-2, 1977.

Tavares, A Faiseau musculaire sternocondroepitrochléen. $C$. R. Assoc. Anat., 29:242-5, 1982.

Testut, L. Les anomalies musculaires chez l'homme. Masson, Paris, 1887.

Yuksel, M.; Yürsel, E. \& Sürücü, S. An axillary arch. Clin. Anat., 9:252-4, 1996.

Williams, P. L.; Warwick, R.; Dyson, M. \& Bannister, L. H. (eds). Gray anatomia. $37^{\text {th }}$ ed. Guanabara Koogan, Rio de Janeiro, 1995. V. 2.

\section{Correspondence to:}

Prof. Dr. Mariano del Sol

Faculty of Medicine

Universidad de La Frontera

Casilla 54-D

Temuco-CHILE

Email: mdelsol@ufro.cl

Received: 15-05-2009

Accepted: 22-06-2009 